\title{
Deformation Behavior of Powder Metallurgy Connecting Rod Preform During Hot Forging Based on Hot Compression and Finite Element Method Simulation
}

\author{
FENGXIAN LI, JIANHONG YI, and JÜRGEN ECKERT
}

\begin{abstract}
Powder-forged connecting rod with a complex geometry shape always has a problem with nonuniform density distribution. Moreover, the physical property of preform plays a critical role for optimizing the connecting rod quality. The flow behavior of a $\mathrm{Fe}-3 \mathrm{Cu}-0.5 \mathrm{C}$ (wt pct) alloy with a relative density of 0.8 manufactured by powder metallurgy $(\mathrm{P} / \mathrm{M}, \mathrm{Fe}-\mathrm{Cu}-\mathrm{C})$ was studied using isothermal compression tests. The material constitutive equation, power dissipation $(\eta)$ maps, and hot processing maps of the $\mathrm{P} / \mathrm{M} \mathrm{Fe}-\mathrm{Cu}-\mathrm{C}$ alloy were established. Then, the hot forging process of the connecting rod preforms was simulated using the material constitutive model based on finite element method simulation. The calculated results agree well with the experimental ones. The results show that the flow stress increases with decreasing temperature and increasing strain rate. The activation energy of the $\mathrm{P} / \mathrm{M} \mathrm{Fe}-\mathrm{Cu}-\mathrm{C}$ alloy with a relative density of 0.8 is $188.42 \mathrm{~kJ} / \mathrm{mol}$. The optimum temperature at the strain of 0.4 for good hot workability of sintered $\mathrm{Fe}-\mathrm{Cu}-\mathrm{C}$ alloy ranges from $1333 \mathrm{~K}$ to $1380 \mathrm{~K}\left(1060{ }^{\circ} \mathrm{C}\right.$ to $\left.1107^{\circ} \mathrm{C}\right)$. The relative density of the hot-forged connecting rod at the central part changed significantly compared with that at the big end and that at the small end. These present theoretical and experimental investigations can provide a methodology for accurately predicting the densification behavior of the $\mathrm{P} / \mathrm{M}$ connecting rod preform during hot forging, and they help to optimize the processing parameters.
\end{abstract}

DOI: $10.1007 / \mathrm{s} 11661-017-4062-5$

(c) The Minerals, Metals \& Materials Society and ASM International 2017

\section{INTRODUCTION}

POWDER metallurgy $(\mathrm{P} / \mathrm{M})$ is a promising approach to reduce production costs and improve material performance, especially in hot forging of connecting rods. The materials saved approximately 20 to $40 \mathrm{pct}$ of the workpiece. Powder forging connecting rod technology combines the advantages of $\mathrm{P} / \mathrm{M}$ and precision forging with high material utilization and mechanical properties; it not only offers a convenient method for incorporating inexpensive alloying elements, but also a good pathway to obtain near-net-shape parts. The powder-forged connecting rod has strong potential for commercial use in the automobile industry.

The powder-forged connecting rod with a complex geometry shape is composed of the small end, the big end, and a beamlike shank. Its manufacturing process involves the fabrication of a connecting rod preform by the conventional $\mathrm{P} / \mathrm{M}$ processing technique, followed by a forging process to its final shape with substantial densification. ${ }^{[1]}$ Generally, the $\mathrm{P} / \mathrm{M}$ connecting rod

FENGXIAN LI and JIANHONG YI are with the Kunming University of Science and Technology, Kunming 650093, China. Contact e-mail: clfxl@scut.edu.cn JÜRGEN ECKERT is with the Erich Schmid Institute of Materials Science, 8700 Leoben, Austria.

Manuscript submitted July 8, 2016.

Article published online March 28, 2017 preforms approximately with a relative density of 0.7 to 0.8 , which always leads to a problem of nonuniform density distribution in the connecting rod.

In order to control hot forging yield in the manufacture of connecting rod with a high density and excellent mechanical properties, it is inevitable to correctly interpret the $\mathrm{P} / \mathrm{M}$ material constitutive model and to properly control the processing parameters. In many cases, the deformation behavior of the $\mathrm{P} / \mathrm{M}$ connecting rod preforms during hot forging has not been fully understood.

Inspection of the available literature demonstrates that the finite element method (FEM) $)^{[2-4]}$ used for mechanical behavior simulation and the hot-pressing map $^{[5-9]}$ is critical in the design analysis process. Liao et al. studied the hot deformation behaviors of $\mathrm{Al}-\mathrm{Si}-\mathrm{Mg}$ alloys by hot compressive tests using a Gleebe-3500 thermal simulator ${ }^{[5]} \mathrm{Xu}$ and Wang used hot compression tests to establish the constitutive equation, power dissipation maps, and hot processing maps of sprayformed LSHR alloy. ${ }^{[6]}$ Yang et al. established the constitutive modeling of the GH4169 superalloy during linear friction welding by thermophysical simulation. ${ }^{[7]}$ It should be noted that the constitutive equation, power dissipation maps, and hot processing maps can provide valuable information about the physical properties of materials. Since there is a substantial amount of porosity content in the $\mathrm{P} / \mathrm{M}$ connecting rod preforms, 
the material flow behavior of the $\mathrm{P} / \mathrm{M} \mathrm{Fe}-\mathrm{Cu}-\mathrm{C}$ alloy during hot forging should be clarified. However, studies focused on the deformation behavior of the $\mathrm{P} / \mathrm{M}$ $\mathrm{Fe}-\mathrm{Cu}-\mathrm{C}$ alloy, during the connecting rods forging processing using power dissipation maps and hot processing maps, are still limited.

The FEM offers the possibility of an effective reduction of the cost and time in the optimization of processing parameters and tool design. ${ }^{[10-12]}$ For example, Skripalenko et al. ${ }^{[13,14]}$ and Micheli et al. ${ }^{[15]}$ simulated the chain processes in the manufacture of metallurgical products. Jaouen et al. built a new three-dimensional (3-D) simulation model for complete chaining of casted and forged ingots. ${ }^{[16]}$ Abdullin and Ershov simulated the casting and metal-forming operations with ProCAST software. ${ }^{[17]}$ It can be seen that in FEM analysis for analyzing the deformation behavior of $\mathrm{P} / \mathrm{M}$ preforms, it is crucial to properly generate entire 3-D FEMs based on the material constitutive model and to apply the actual forging load and boundary conditions. According to the latest survey, the hot deformation behavior of $\mathrm{P} / \mathrm{M}$ materials has experienced great development. However, there are still some uncertainties concerning the hot deformation behavior of the $\mathrm{P} / \mathrm{M}$ $\mathrm{Fe}-\mathrm{Cu}-\mathrm{C}$ alloy, especially during the hot forging connecting rods processing.

In this work, hot compression tests were performed on a $\mathrm{P} / \mathrm{M}$ Fe- $\mathrm{Cu}-\mathrm{C}$ alloy with a relative density of 0.8 at different strain rates. The constitutive equation, power dissipation maps, and hot processing maps for hot deformation of the $\mathrm{P} / \mathrm{M}$ Fe-Cu-C alloy were established. Based on the hot compression experimental results, the hot deformation behavior of preforms was predicted by the FEM while considering the shape gradient of the connecting rod and the actual boundary conditions during hot forging. A comprehensive study on the metal flow behavior of the $\mathrm{P} / \mathrm{M} \mathrm{Fe}-\mathrm{Cu}-\mathrm{C}$ alloy during hot forging based on the numerical simulation and the experimental results can provide insights into the manipulation and optimization of the processing parameters for achieving full density of the connecting rod.

\section{EXPERIMENTAL METHODS AND MODELING}

$\mathrm{P} / \mathrm{M} \mathrm{Fe}-3 \mathrm{Cu}-0.5 \mathrm{C}$ (wt pct) alloy with an average relative density of 0.8 was selected as the model material. Then, samples with diameter of $8 \mathrm{~mm}$ and height of $12 \mathrm{~mm}$ were prepared for the isothermal compression test. The isothermal compression tests were carried out on a Gleeble-3500 thermal simulator at temperatures of $1333 \mathrm{~K}, 1363 \mathrm{~K}, 1393 \mathrm{~K}$, and 1423 $\mathrm{K}\left(1060{ }^{\circ} \mathrm{C}, 1090^{\circ} \mathrm{C}, 1120^{\circ} \mathrm{C}\right.$, and $\left.1150{ }^{\circ} \mathrm{C}\right)$ and strain rates of $5,11.5$, and $19.2 \mathrm{~s}^{-1}$. Specimens were heated by induction coils at a heating rate of $5 \mathrm{~K} / \mathrm{s}$ and soaked for 10 seconds by the thermocouple feedback control before compression. The specimens were compressed to a final strain of 0.6 . The true strain-stress curves were recorded automatically.

The flow stress $(\sigma, \mathrm{MPa})$ in hot deformation depends on the temperature $(T, \mathrm{~K})$ and strain rate $\left(\dot{\varepsilon}, \mathrm{s}^{-1}\right)$. The relationship among $\sigma, T$, and $\dot{\varepsilon}$ can be generally expressed in terms of the kinetic rate equation given by Zener and Hollomon ${ }^{[18]}$ and Shi et al. ${ }^{[19]}$.

$$
\dot{\varepsilon}=A[\sinh (\alpha \sigma)]^{n} \exp [-Q /(R T)],
$$

where $\alpha$ is a constant independent of the deformation temperature, $n$ is the stress exponent, $A$ is the structure factor, $\mathrm{s}^{-1}$, and $R$ is the universal gas constant, $8.314 \mathrm{~J} / \mathrm{mol}$. The term $Q$ is the activation energy of hot deformation $(\mathrm{J} / \mathrm{mol})$ and can be calculated as follows:

$$
Q=R\left\{\frac{\partial \ln \dot{\varepsilon}}{\partial \ln [\sinh (\alpha \sigma)]}\right\}_{T}\left\{\frac{\partial \ln [\sinh (\alpha \sigma)]}{\partial(1 / T)}\right\}_{\dot{\varepsilon}} .
$$

The power dissipation capacity of the material can be described by the efficiency of power dissipation $(\eta)$ based on the principles of the dynamic material model ${ }^{[20]}$ :

$$
\eta=\frac{2 m}{m+1}
$$

where $m$ is the strain rate sensitivity index caused by viscous plastic deformation and can be calculated by the following equation at each strain rate:

$$
m=\frac{\partial \log \sigma}{\partial \log \dot{\varepsilon}} .
$$

Finally, the power dissipation map can be plotted as a 3 -D map of $\eta-T-\dot{\varepsilon}$. Moreover, some variations of instability, such as wedge crack and pore, should be considered. The instability domain in the processing map can be evaluated by the following criterion ${ }^{[21]}$.

$$
\xi(\dot{\varepsilon})=\frac{\partial \log (m / m+1)}{\partial \log \dot{\varepsilon}}+m<0 .
$$

When $n$ is negative, flow instabilities are predicted to occur.

Based on the hot compression experimental results, the constitutive equation of the $\mathrm{P} / \mathrm{M} \mathrm{Fe}-\mathrm{Cu}-\mathrm{C}$ alloy can be obtained and imported into the commercial DEFORM-3-D plastic forming software for the

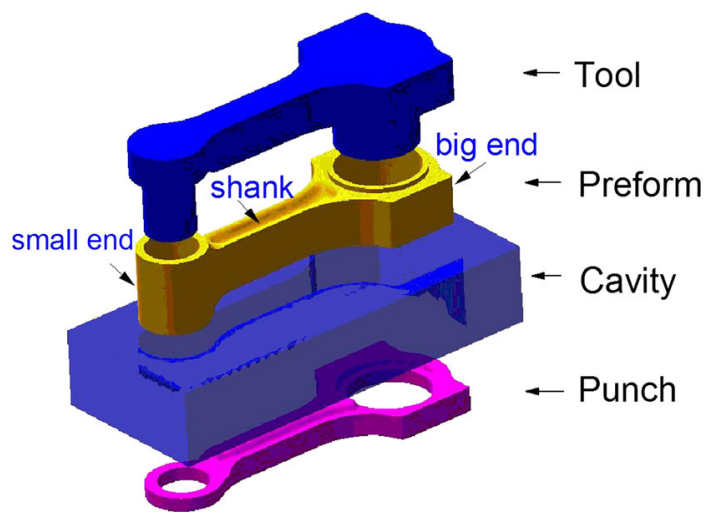

Fig. 1-Geometrical model assembly of tool, punch, preform, and cavity. 
simulation. The deformation behaviors of the $\mathrm{P} / \mathrm{M}$ $\mathrm{Fe}-\mathrm{Cu}-\mathrm{C}$ alloy connecting rod preform during hot forging were simulated. First, the whole 3-D-FEMs were established, as shown in Figure 1. The definition of the element mesh used isoparametric four-node elements, foreseeing the discretization of the $\mathrm{P} / \mathrm{M}$ preform and the mold as well as the schematization of the contact between the bodies. As shown in Table I, the connecting rod is divided into 72,341 elements and 17,645 nodes. The setting of the mesh density in the deformation zones was varied according to the strain or strain rate distributions. The thermophysical properties of mold, H13, are list in Table II. The finite element code is based on the flow formulation approach using an updated Lagrange procedure.

Table I. Element Numbers and Nodes of 3-D Mesh

\begin{tabular}{lcccr}
\hline & Preform & Tool & Cavity & Punch \\
\hline Elements & 72,341 & 75,770 & 64,400 & 14,494 \\
Nodes & 17,645 & 17,097 & 15,145 & 60,779 \\
\hline
\end{tabular}

Table II. Thermophysical Properties of H13

\begin{tabular}{lccc}
\hline Temperature & $293 \mathrm{~K}\left(20{ }^{\circ} \mathrm{C}\right)$ & $573 \mathrm{~K}\left(300{ }^{\circ} \mathrm{C}\right)$ & $773 \mathrm{~K}\left(500{ }^{\circ} \mathrm{C}\right)$ \\
\hline Elastic modulus $\left(10^{11} \mathrm{~Pa}\right)$ & 2.10 & 1.91 & 1.75 \\
Thermal conductivity $(\mathrm{W} / \mathrm{m} / \mathrm{K})$ & 36.6 & 32.1 & 29.7 \\
Heat capacities per unit mass $(\mathrm{J} / \mathrm{kg} / \mathrm{K})$ & 445.6 & 553 & 641 \\
\hline
\end{tabular}

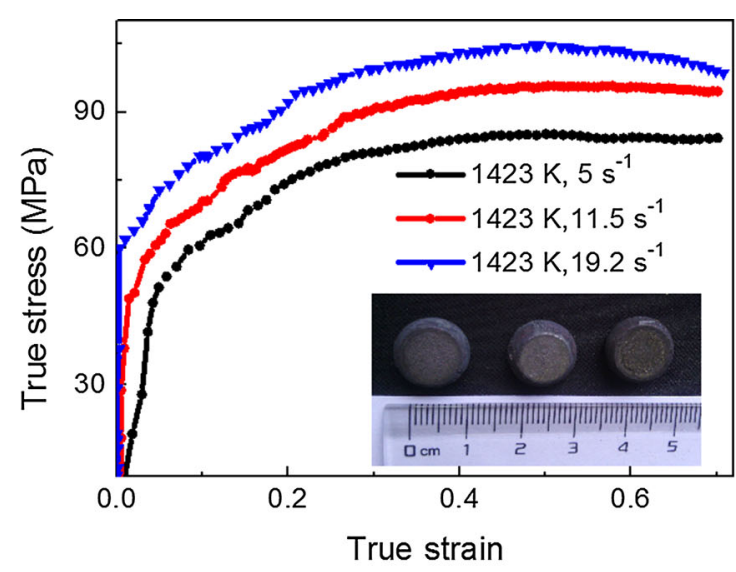

(a)

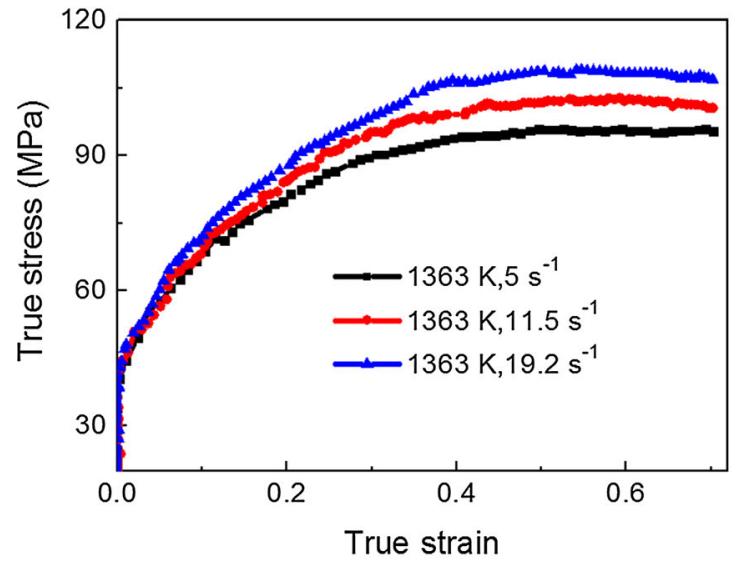

(c)

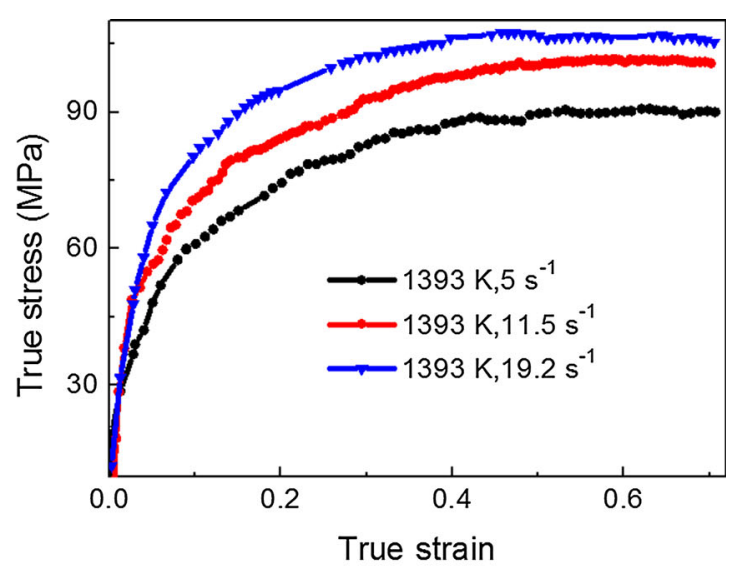

(b)

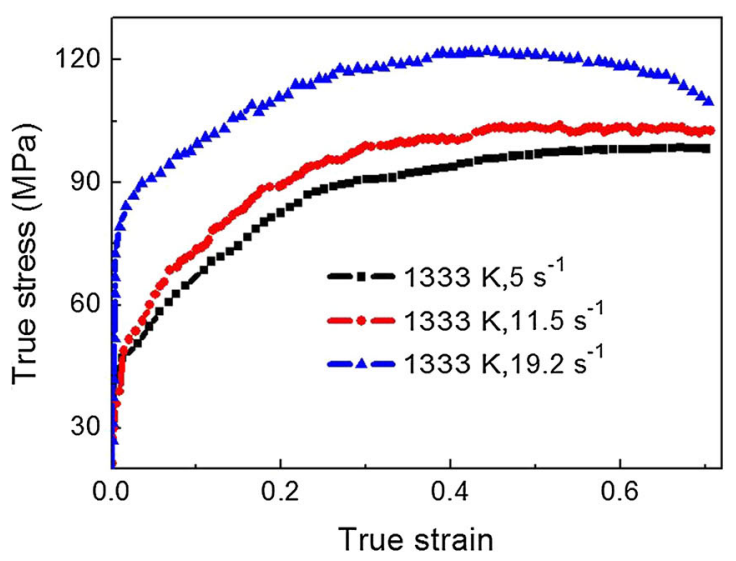

(d)

Fig. 2-Stress-strain curves for the $\mathrm{P} / \mathrm{M} \mathrm{Fe}-\mathrm{Cu}-\mathrm{C}$ alloy at different temperatures and various stain rates: $\left(\right.$ a) $1423 \mathrm{~K}\left(1150{ }^{\circ} \mathrm{C}\right),(b) 1393 \mathrm{~K}$ $\left(1120^{\circ} \mathrm{C}\right),(c) 1363 \mathrm{~K}\left(1090{ }^{\circ} \mathrm{C}\right)$, and $(d) 1333 \mathrm{~K}\left(1060{ }^{\circ} \mathrm{C}\right)$. 


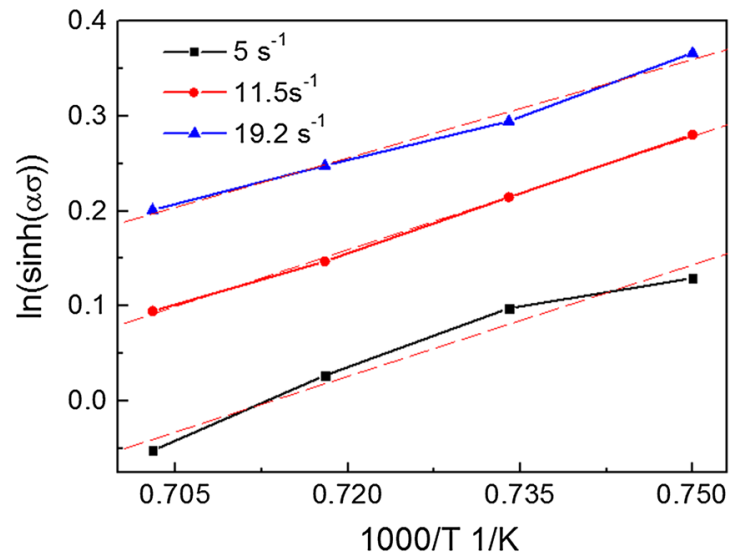

(a)

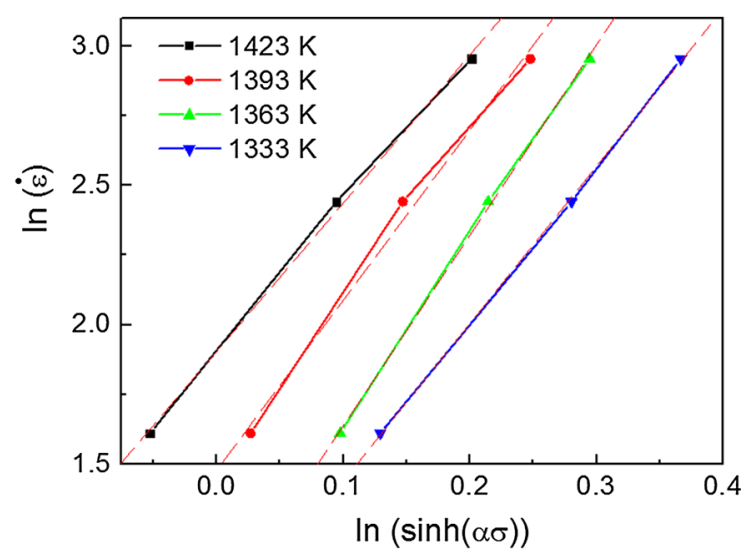

(b)

Fig. 3-Relationships of $(a) \ln [\sinh (\alpha \sigma)]$ and $1 / T$ and $(b) \ln \dot{\varepsilon}$ and $\ln [\sinh (\alpha \sigma)]$.

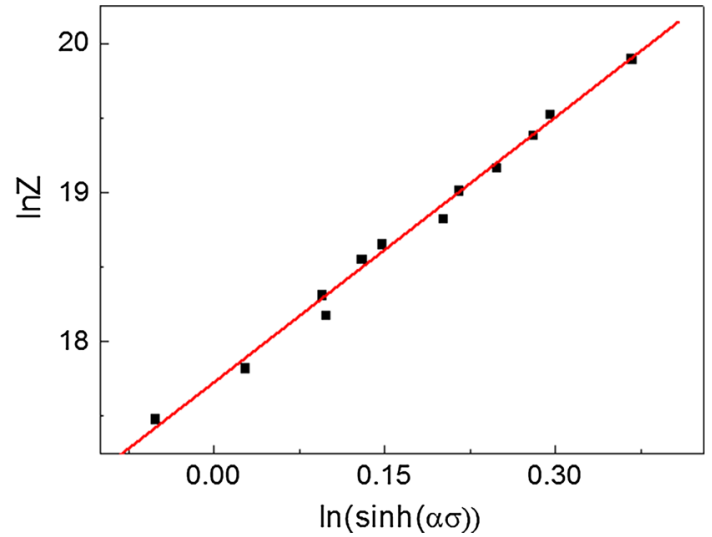

Fig. $4-$ Relationship of $\ln Z$ and $\ln [\sinh (\alpha \sigma)]$.

In this work, the deformation temperatures and forging velocities corresponding to the high and unique density distribution can be considered as suitable candidates for hot working parameters.

\section{RESULTS AND DISCUSSION}

\section{A. Flow Stress Characteristics and Flow Constitutive Equation}

The experimental true stress-strain curves of the $\mathrm{P} / \mathrm{M}$ $\mathrm{Fe}-\mathrm{Cu}-\mathrm{C}$ alloy at different temperatures and various stain rates from the hot compression test are presented in Figure 2, which indicates that the $\mathrm{P} / \mathrm{M} \mathrm{Fe}-\mathrm{Cu}-\mathrm{C}$ alloy is very sensitive to deformation temperature and strain rate. The flow stress level decreases greatly with an increase in temperature at the same strain rate.

As we know, a higher temperature can improve the mobility of the grain boundary for the nucleation and growth of grains, which leads to a decrease of flow stress level. Moreover, the flow stress level increases greatly with an increase in strain rate at the same temperature (Figure 2). A lower strain rate can provide a longer time for activation energy accumulation.
For low and high stress levels, a natural logarithm is taken at both sides of $\sigma$ and $\dot{\varepsilon}$; then, the corresponding value of $\ln \sigma$ and $\ln \dot{\varepsilon}$ can be obtained and plots $\ln \sigma \sim \ln \dot{\varepsilon}$ and line $\sigma \sim \ln \dot{\varepsilon}$. The average values of slopes are used to derive the values of $n$ and $\beta$, which are 7.86629 and 0.078 $\mathrm{MPa}^{-1}$, respectively. Therefore, $\alpha=\beta / n=0.01 \mathrm{MPa}^{-1}$.

Figure 3 shows the dependence of $\ln [\sinh (\alpha \sigma)]$ on $1 / T$ and the relationship between $\ln [\sinh (\alpha \sigma)]$ and $\ln$. The average slope values of two lines, $\ln \sim \ln [\sinh (\alpha \sigma)]$ and $\ln [\sinh (\alpha \sigma)] \sim 1 / T$, derive the values of $n$ and $K$, which are 5.99 and 3.78, respectively.

Finally, $Q$ of the $\mathrm{P} / \mathrm{M} \mathrm{Fe}-\mathrm{Cu}-\mathrm{C}$ alloy during hot compression is calculated as $188.42 \mathrm{~kJ} / \mathrm{mol}$ according to Eq. [6].

$$
Q=R n K \text {. }
$$

Generally, $Z$, in Eq. [7], can be used to characterize the combined effect of strain rate and temperature on the deformation process, in particular, the deformation resistivity. ${ }^{[21]}$

$$
\ln Z=\ln \dot{\varepsilon}+Q /(R T)
$$

The linear relationship between $\ln Z$ and $\ln [\sinh (\alpha \sigma)]$ is plotted in Figure 4, along with the linear regression lines. For $\mathrm{P} / \mathrm{M} \mathrm{Fe}-\mathrm{Cu}-\mathrm{C}$ alloys, the more accurate values of $n$ and $\ln A$ are determined as 5.93 and 17.73, respectively.

Therefore, under the deformation conditions over a temperature range of $1333 \mathrm{~K}$ to $1423 \mathrm{~K}\left(1060{ }^{\circ} \mathrm{C}\right.$ to $1150{ }^{\circ} \mathrm{C}$ ), the constitutive equation of the $\mathrm{P} / \mathrm{M} \mathrm{Fe}-\mathrm{Cu}-\mathrm{C}$ alloy with a relative density of 0.8 is obtained as follows:

$$
\dot{\varepsilon}=5 \times 10^{7}[\sinh (0.01 \sigma)]^{5.93} \exp [-188,420 /(8.314 T)] .
$$

In order to verify the predictive accuracy of the developed constitutive $\mathrm{P} / \mathrm{M}$ Fe-Cu-C alloys, a comparison between the experimental results and predicted stresses from the developed constitutive equation (Eq. [8]) is shown in Table III. The values reveal a high accuracy. Namely, the flow stress of the studied alloys 
Table III. Comparison Between the Experimental and Predicted Stresses During Hot Compression

\begin{tabular}{lcccc}
\hline Strain Rate $\left(\mathrm{s}^{-1}\right)$ & Temperature $\left[\mathrm{K}\left({ }^{\circ} \mathrm{C}\right)\right]$ & Experimental $(\mathrm{MPa})$ & Calculated $(\mathrm{MPa})$ & Relative Mistake $(\mathrm{Pct})$ \\
\hline 5 & $1423(1150)$ & 85.838 & 87.303 & 1.708 \\
5 & $1393(1120)$ & 91.314 & 89.476 & 2.012 \\
5 & $1363(1090)$ & 98.769 & 94.097 & 4.729 \\
5 & $1333(1060)$ & 98.683 & 95.564 & 3.161 \\
11.5 & $1423(1150)$ & 95.789 & 98.338 & 2.659 \\
11.5 & $1393(1120)$ & 101.558 & 97.531 & 1.995 \\
11.5 & $1363(1090)$ & 102.895 & 100.495 & 4.952 \\
11.5 & $1333(1060)$ & 103.511 & 98.307 & 2.913 \\
19.2 & $1423(1150)$ & 99.995 & 100.411 & 1.688 \\
19.2 & $1393(1120)$ & 102.469 & 106.364 & 2.009 \\
19.2 & $1363(1090)$ & 105.064 & 111.242 & 1.238 \\
19.2 & $1333(1060)$ & 111.938 & 0.621 \\
\hline
\end{tabular}

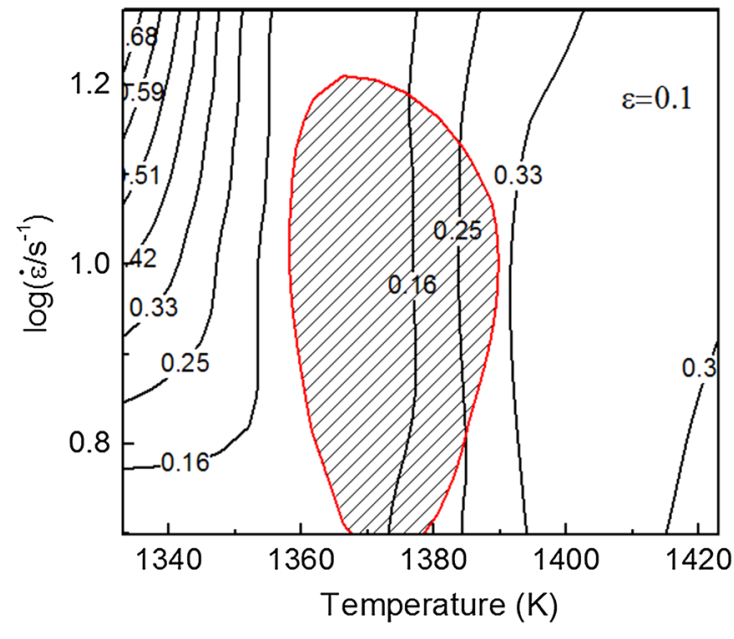

(a)

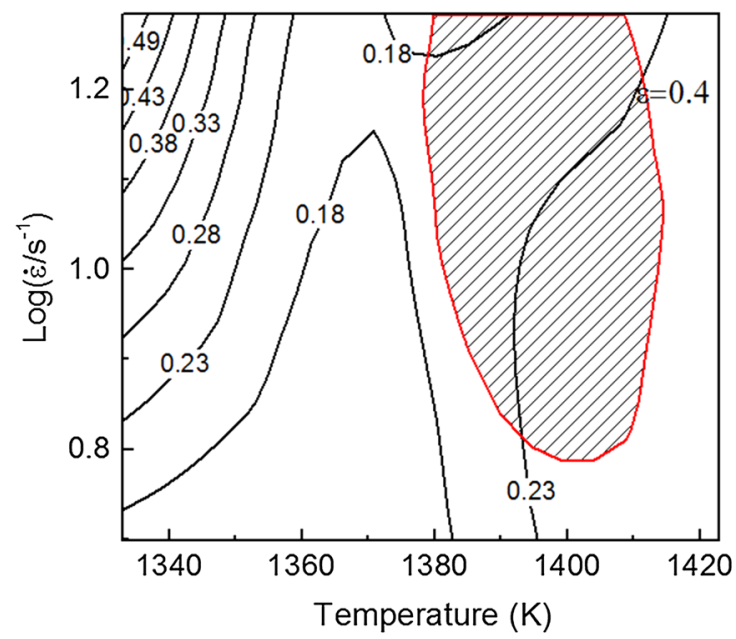

(c)

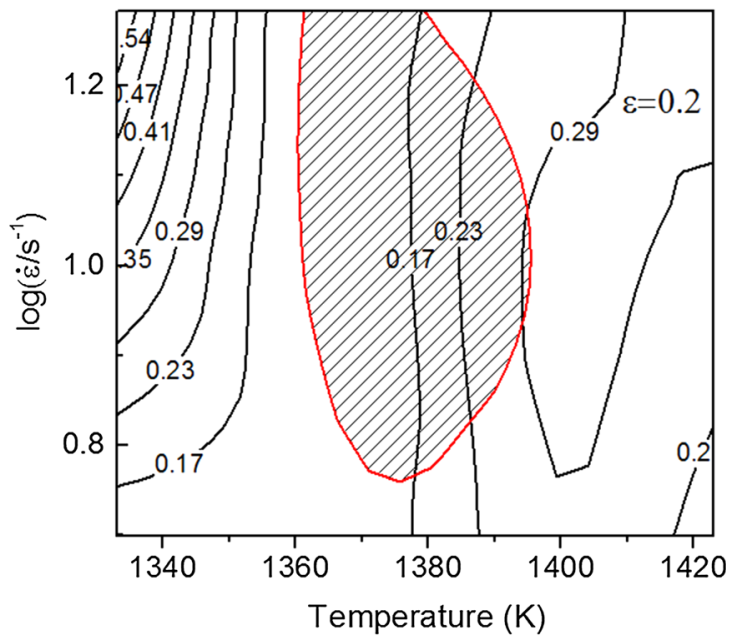

(b)

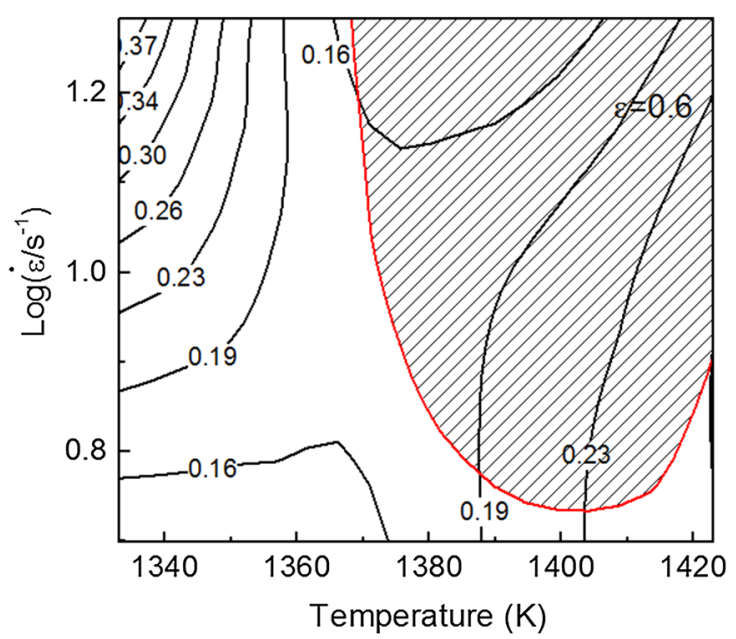

(d)

Fig. 5-Processing maps of $\mathrm{P} / \mathrm{M} \mathrm{Fe}-\mathrm{Cu}-\mathrm{C}$ alloys during hot compression at different strains: $(a)$ 0.1, (b) 0.2, (c) 0.4, and (d) 0.5 . 


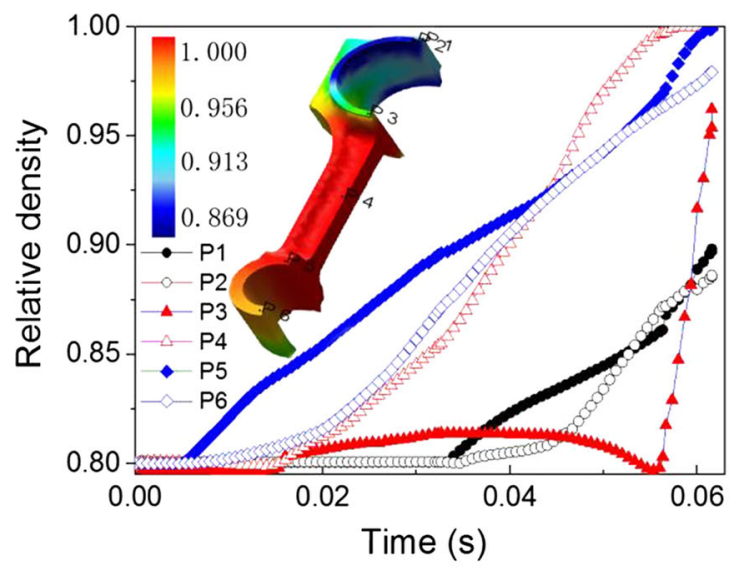

(a)

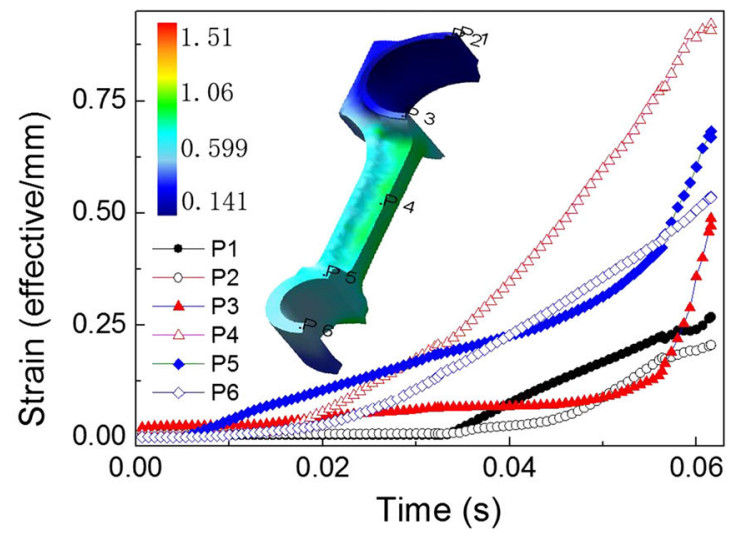

(c)

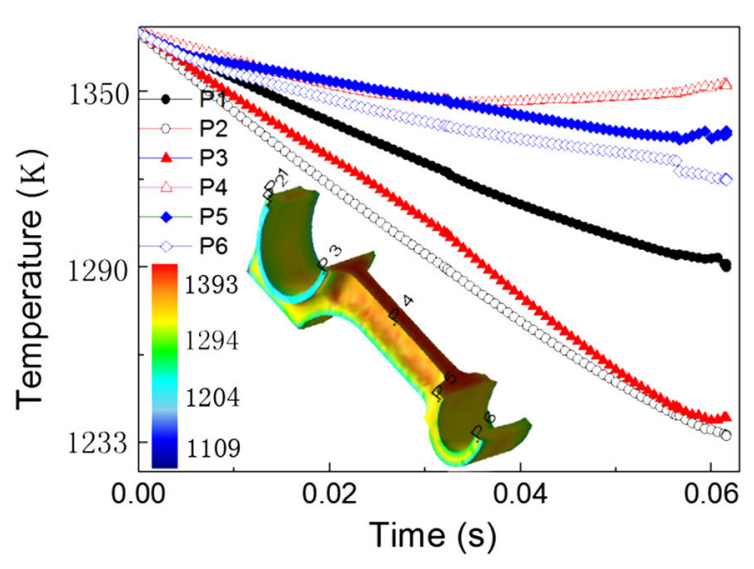

(b)

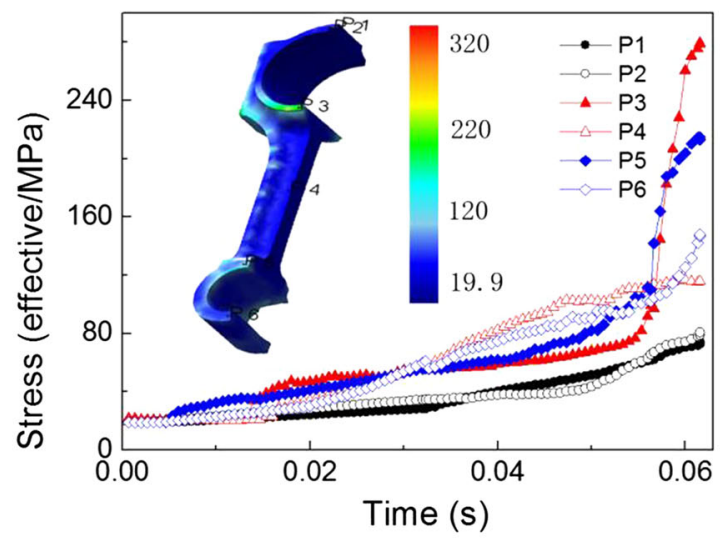

(d)

Fig. 6-(a) Relative density, (b) temperature, $(c)$ effective strain, and (d) effective stress distributions at various forging times.

during hot deformation at a wide strain rate (5 to 19.2 $\mathrm{s}^{-1}$ ) can be predicted accurately by Eq. [8].

\section{B. Processing Maps}

Figure 5 shows the constructed processing maps of $\mathrm{Fe}-\mathrm{Cu}-\mathrm{C}$ alloys during hot compression at a temperature ranging from $1333 \mathrm{~K}$ to $1423 \mathrm{~K}\left(1060{ }^{\circ} \mathrm{C}\right.$ to $\left.1150{ }^{\circ} \mathrm{C}\right)$ and strain rates ranging from 5 to $11.5 \mathrm{~s}^{-1}$ with strains of 0.1 , $0.2,0.4$, and 0.5 . The diagonal region represents the instability domains. With the increase of strain, as shown in Figures 5(a) through (d), the instability domain is significantly increased, especially at high temperature, as shown in Figure 5(d). This can be attributed to the fact that wedge crack and pore may occur during hot deformation at a large strain. Moreover, with increasing strain, the peak power dissipation efficiency decreases, as shown in Figure 5, meaning that alloys are more difficult to hot deform than those at small strain. For a strain of 0.4 , the optimal hot working parameters for the $\mathrm{P} / \mathrm{M}$ $\mathrm{Fe}-\mathrm{Cu}-\mathrm{C}$ alloy are at a deformation temperature ranging from $1333 \mathrm{~K}$ to $1380 \mathrm{~K}\left(1060{ }^{\circ} \mathrm{C}\right.$ to $\left.1107{ }^{\circ} \mathrm{C}\right)$ and at a lower strain rate than $5 \mathrm{~s}^{-1}$. However, for a strain of 0.6 , they are at a temperature ranging from $1333 \mathrm{~K}$ to $1370 \mathrm{~K}$ $\left(1060{ }^{\circ} \mathrm{C}\right.$ to $\left.1097^{\circ} \mathrm{C}\right)$ and at a lower strain rate than $5 \mathrm{~s}^{-1}$.
According to the processing map in Figure 5, the stable and unstable deformation regimes can be clearly seen. However, the metal flow behavior of the preform varies in a complicated manner during the hot forging process. It is necessary to obtain the deformation behavior of the $\mathrm{P} / \mathrm{M}$ Fe-Cu-C alloy connecting rod preform during the hot forging process from FEM simulation results.

\section{FEM Simulation Results}

The developed constitutive equation, Eq. [8], can be used to analyze and simulate the deformation behaviors of materials during the hot working process in the FEM. For hot forging of the $\mathrm{P} / \mathrm{M} \mathrm{Fe}-\mathrm{Cu}-\mathrm{C}$ alloy with a relative density of 0.8 in a closed die, with a forging velocity of $250 \mathrm{~mm} / \mathrm{s}$, an initial preform temperature of $1373 \mathrm{~K}\left(1100{ }^{\circ} \mathrm{C}\right)$, and a preheated model temperature of $573 \mathrm{~K}\left(300{ }^{\circ} \mathrm{C}\right)$, the whole 3-D-FEMs of the connecting rod preforms are effectively generated. The heat conductivity and the activation energy of the $\mathrm{P} / \mathrm{M}$ $\mathrm{Fe}-\mathrm{Cu}-\mathrm{C}$ alloy are $5.8 \mathrm{~W} / \mathrm{m} \mathrm{K}^{[22]}$ and $188.42 \mathrm{~kJ} / \mathrm{mol}$, respectively. In order to reduce the alloy oxidation and the friction between the workpiece and dies during the forging process, lubricants are painted on the surface of 
the preform. Therefore, a friction coefficient of 0.4 was selected.

The relative density, temperature, effective strain, and effective stress variations of the connecting rod preform at different times are shown in Figure 6. Some representative points were selected to study the different areas of the connecting rod: $\mathrm{P} 1, \mathrm{P} 2$, and $\mathrm{P} 3$ are points on the surface of the position at the big end, $\mathrm{P} 4$ is a point on

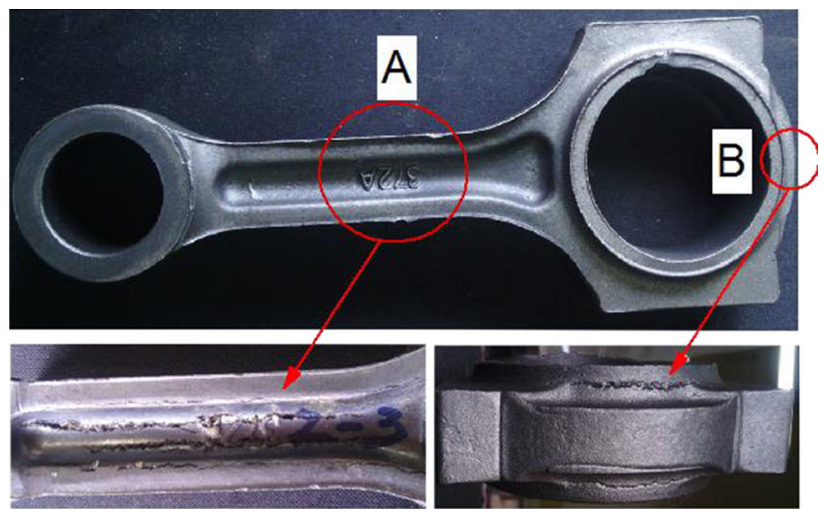

Fig. 7-P/M Fe-Cu-C alloy connecting rod forged at $1373 \mathrm{~K}$ $\left(1100{ }^{\circ} \mathrm{C}\right)$. the surface of the position at the shank, and P5 and P6 are points on the surface of the position at the small end. Figure 6(a) shows the relative density distributions of the connecting rod preform during hot forging. It is clear that the relative density increases dramatically at the shank (P4) and the small end (P5), and the final relative densities can reach 1.0. As we know, the initial temperature of the preforms and the preheating temperature of dies play a critical role in the thermal profiles of materials. During the hot forging process, the heat loss between the connecting rod and molds is pronounced; the temperature of the material in all the areas decreases with increasing forging time, as shown in Figure 6(b). The temperature of most parts of the connecting rod is above $1233 \mathrm{~K}\left(960{ }^{\circ} \mathrm{C}\right)$. However, the cooling rate at the shank of the connecting rod, such as P4, decreased more slowly than that near the big end (P2) and the small end (P6). This can be attributed to the balance between the heat generated by plastic deformation and heat loss due to conduction, convection, and radiation.

Figures 6(c) and (d) show the variations of effective stress and effective strain distributions at typical points at different forging times. The curves of the effective stress and the effective strain at different parts of the forging increased slowly at first and then increased

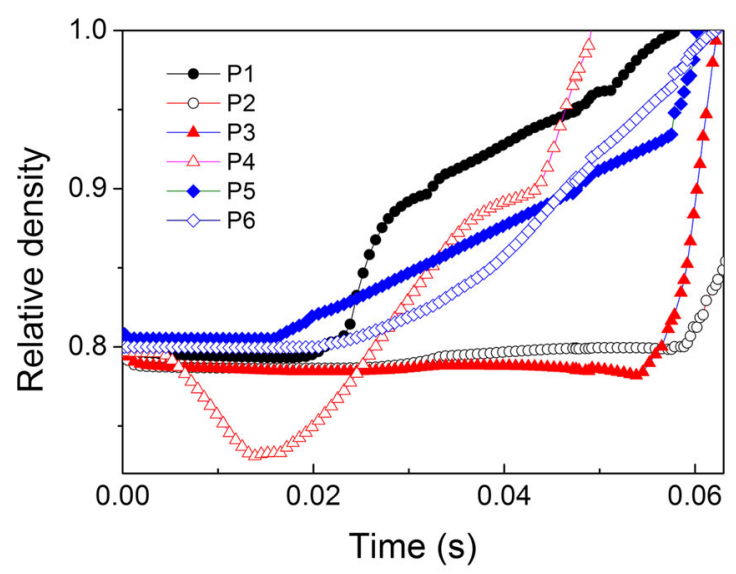

(a)

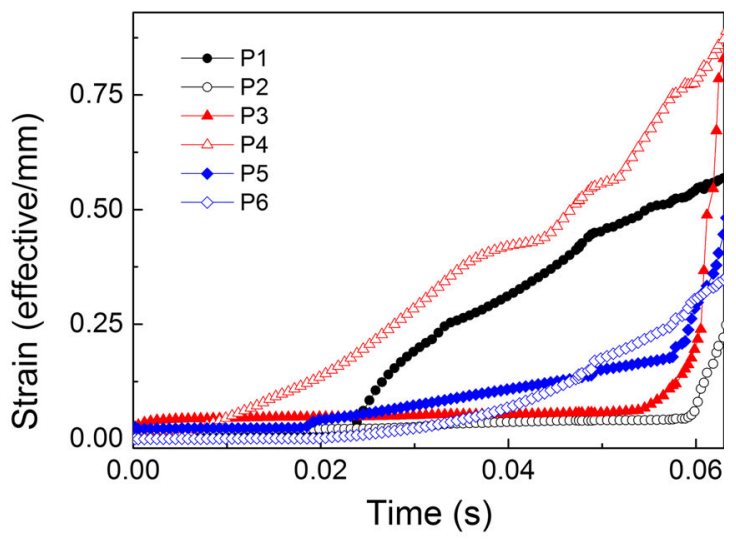

(b)

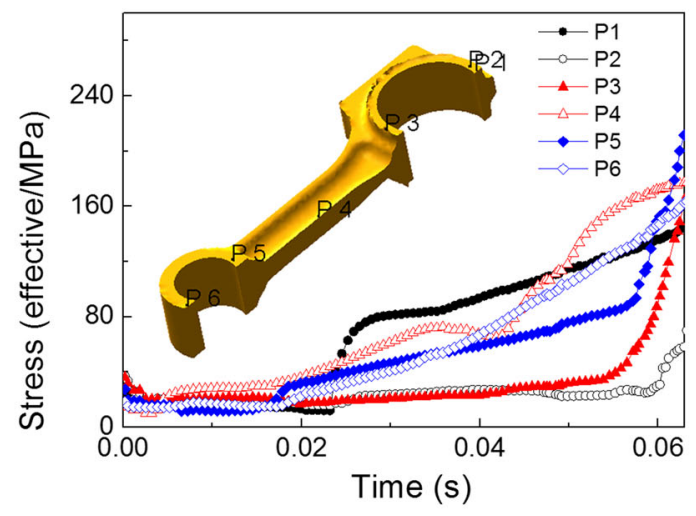

(c)

Fig. 8- (a) Relative density, (b) effective strain, and (c) effective stress distributions at various forging times. 
dramatically. Moreover, the results indicate that the larger the deformation is, the larger the effective stress and the effective strain are, i.e., $\mathrm{P} 4$.

Based on the processing map and the results of FEM simulation, the optimum processing parameters to achieve full density of the connecting rod are obtained as follows: the forging velocity is $250 \mathrm{~mm} / \mathrm{s}$, the hot forging temperature is $1373 \mathrm{~K}\left(1100{ }^{\circ} \mathrm{C}\right)$, and the initial temperature of deformation in most of the parts is above $1233 \mathrm{~K}\left(960^{\circ} \mathrm{C}\right)$ in the whole forging process. The $\mathrm{P} / \mathrm{M}$ $\mathrm{Fe}-\mathrm{Cu}-\mathrm{C}$ alloy connecting the rod preform was also forged under the same conditions, as shown in Figure 7(a). This demonstrates that the calculated results agree well with the experimental results.

However, if the process parameters are not controlled properly, the design of the hot forging of the connecting rod will fail. For the hot forging process of the connecting rod preforms with a forging velocity of $230 \mathrm{~mm} / \mathrm{s}$, friction coefficient of $0.4 \mathrm{~m}$, initial preform temperature of $1273 \mathrm{~K}$ $\left(1000{ }^{\circ} \mathrm{C}\right)$, and preheated model temperature of $473 \mathrm{~K}$ $\left(200{ }^{\circ} \mathrm{C}\right)$, the quality of the forged connecting rod is very low. When the forging process stops suddenly at a forging time of 0.018 seconds, the damage occurs at P4, as shown in Figure 7 (point A) and Figure 8 (P4). There is a large deformation at the central part of the connecting rod, i.e., a relatively high strain (Figure 8(b)) and high stress level (Figure 8(c)), compared with that at other positions, such as P3 and P5 in Figure 8(b).

In addition, the relative density of the hot-forged connecting rod at the big end, as shown in Figure 7 (point B) and Figure 8 (P2), is relatively low compared with that of P1, due to insufficient deformation.

This work provides insights into manipulating the powder forging processing parameters of the connecting rod. Furthermore, the preform geometric size also plays a crucial part in the magnitude of the relative density and should be further studied.

\section{CONCLUSIONS}

The flow behavior of a $\mathrm{P} / \mathrm{M}$ Fe-Cu-C (wt pet) alloy with a relative density of 0.8 produced by the $\mathrm{P} / \mathrm{M}$ route was studied using isothermal compression tests. The constitutive equation, power dissipation maps, and hot processing maps of the $\mathrm{P} / \mathrm{M}$ Fe-Cu-C alloy were developed. Then, the hot forging process of the connecting rod preforms was simulated by the FEM-based material constitutive model. The calculated results agree well with the experimental results. The results show that the flow stress increases with decreasing temperature and increasing strain rate. The activation energy of the $\mathrm{P} / \mathrm{M}$ Fe-Cu-C alloy with a relative density of 0.8 is $188.42 \mathrm{~kJ} / \mathrm{mol}$. The optimum temperature at the strain of 0.4 for good hot workability of the $\mathrm{P} / \mathrm{M}$ $\mathrm{Fe}-\mathrm{Cu}-\mathrm{C}$ alloy ranges from $1333 \mathrm{~K}$ to $1380 \mathrm{~K}\left(1060{ }^{\circ} \mathrm{C}\right.$ to $1107^{\circ} \mathrm{C}$ ). The relative density of the hot-forged connecting rod at the shank changed heavily compared with that at the big end and at the small end. This work provides insights into manipulating the processing parameters during hot forging for achieving full density of the connecting rod.

\section{ACKNOWLEDGMENTS}

The authors gratefully acknowledge the financial support of the National Natural Science Foundation of China (Project Nos. 51664034, 51461026, 51274107, and 51361017).

\section{REFERENCES}

1. R.M. German: Powder Metallurgy of Iron and Steel, Wiley, New York, 1998, pp. 276-79.

2. D. Gopinath and C.V. Sushma: Mater. Today Proc., 2015, vol. 2, pp. 2291-99.

3. P.C. Lu: Int. J. Mater. Prod. Technol., 1996, vol. 11, pp. 357-70.

4. W. Liu, F.G. Lu, R.J. Yang, X.H. Tang, and H.C. Cui: J. Mater. Process. Technol., 2015, vol. 225, pp. 221-28.

5. H.C. Liao, Y.N. Wu, K.X. Zhou, and J. Yang: Mater. Des., 2015, vol. 65, pp. 1091-99.

6. Y. Xu and J. Wang: Trans. Nonferr. Met. Soc. China, 2016, vol. 26, pp. 1032-43.

7. X.W. Yang, W.Y. Li, J. Ma, S.T. Hu, Y. He, L. Li, and B. Xiao: J. Alloys Compd., 2016, vol. 656, pp. 395-407.

8. Y.C. Lin, L.T. Li, Y.C. Xia, and Y.Q. Jiang: J. Alloy. Compd., 2013, vol. 550, pp. 438-45.

9. M.S.V.S. Narayana, R.B. Nageswara, and P. Kashyap: J. Mater. Process. Technol., 2005, vol. 166, pp. 268-78.

10. M. Yu, Y.D. Luo, X.H. Peng, and Y.H. Qin: Trans. Nonferr. Met. Soc. China, 2006, vol. 16, pp. 671-75.

11. F.X. Li, Y.Z. Liu, and J.H. Yi: Metall. Mater. Trans. A, 2014, vol. 45A, pp. 4012-21.

12. F.X. Li, Y.Z. Liu, J. You, and X. Luo: Int. J. Adv. Manuf. Technol., 2013, vol. 67, pp. 2771-78.

13. M.M. Skripalenko, V.E. Bazhenov, B.A. Romantsev, M.N. Skripalenko, A.V. Koltygin, and A.A. Sidorov: Metallurgist, 2014, vol. 58, pp. 86-90.

14. M.M. Skripalenko, V.E. Bazhenov, B.A. Romantsev, M.N. Skripalenko, T.B. Huy, and Y.A. Gladkov: Mater. Sci. Technol., 2016, vol. 32, pp. 1712-20.

15. P. De Micheli, A. Settefrati, S. Marie, J. Barlier, and P. Lasne: Proc. Int. Conf. on 'New Development in Forging Technology', Stuttgart, Germany, 2015, pp. 1-25.

16. O. Jaouen, F. Costes, and P. Lasne: Proc. 1st Int. Conf. on 'Ingot Casting, Rolling and Forging', Aachen, Germany, 2012, pp. 1-9.

17. A.D. Abdullin and A.A. Ershov: Metallurgist, 2014, vol. 58, pp. $339-45$.

18. C. Zener and J.H. Hollomon: J. Appl. Phys., 1944, vol. 15, pp. 22-32.

19. H. Shi, A.J. McLaren, and C.M. Sellars: Mater. Sci. Eng., 1997, vol. 13, pp. 210-16.

20. Y.V.R.K. Prasad and T. Seshacharyulu: Int. Mater. Rev., 1998, vol. 43, pp. 243-47.

21. H. Ziegler: in Progress in Solid Mechanics, I.N. Sneddon and R. Hill, eds., Wiley, New York, 1963, vol. 4, pp. 191-93.

22. J.W. Qiu, Y. Liu, B. Liu, Y.B. Liu, B. Wang, E. Ryba, and H.P. Tang: J. Mater. Sci., 2012, vol. 47, pp. 3837-48. 